\title{
TÜRKIYYE'DE BİR İLK: İZMİR MATZA (HAMURSUZ) FABRİKASI HAKKINDA BELGELER
}

\author{
Siren Bora*
}

\section{Giriş}

Matza ya da Anadolu'da halk arasında bilinen ve tanınan adiyla Hamursur, ${ }^{1}$, Pesah Bayramı'nın ilk iki gecesi olan Seder'de ${ }^{2}$ ve bayram süresince yenilen sembolik yiyeceklerden biridir. Ülkemizde, Hamursuz adeta Pesah ile özdeşleşmiştir. Bu yüzden Pesah Bayramı, Hamursuz Bayramı adıyla bilinmektedir. Batilılar tarafindan ise, "mayasız ekmek bayramı" olarak bilinir ${ }^{3}$. Hamursuz'un iki sembolik anlamı mevcuttur: Kölelik ve özgürlük. Köleliği temsil etmektedir4; çünkü, İsrailoğullarının Mısır'da ağır işlerde çalıştırıldıkları zaman, onlara, hamurun mayalanması için hiç zaman tanınmamıştır. Bu yüzden ekmekler mayalanmadan pişirilmiş ve ona elem ekmeği adı verilmiştir ${ }^{5}$. Özgürlüğü temsil etmektediro; çünkü, Mısır'dan Çıkış, çok hızlı olduğu için, hamurun mayalanmasına vakit kalmamıştır.

Tora'da ${ }^{7}$ ad1 geçen bayramların ilki olan Pesah, Şavout ${ }^{8}$ ve Sukkot ${ }^{9}$ bayramları ile birlikte, "Üç Hac ya da Üç Ayak Bayramları" (רגלים שלוש ) (רגוש ) adlandırılır. Pesah Bayramı, İbrani takvimindeki Nisan ayının 15'inde başlamaktadır ${ }^{10}$. Tora'da bu bayram için iki farklı ad kullanılmaktadır: Pesah, ve Hag

* Tarih Doktoru, Araştırmacı Yazar.

1 Ülkemizde Matza'nın, Hamursuz adıla tanınmasından dolayı, makalemizde, Hamursuz sözcüğünü kullanacağız.

2 İbranice olan Seder, düzen anlamına gelir. Aile, Seder sofrasında bir araya toplanır.

3 Jewish Values, Israel Pocket Library - Keter Publishing House Jerusalem Ltd., Jerusalem 1974, s. 288.

4 "Onunla mayalı ekmek yemeyeceksin; hayatımın bütün günlerinde Misır diyarnndan çıtığın günü hatırlayasın diye onunla yedi gün mayasız ekmĕgi; düskeünlük ekmeğini yiyeceksin; çünkü Misır diyarndan acele ile çıtın”. Tesniye 16:3.

5 Yusuf Besalel, Yabudilik Ansiklopedisi, Cilt 2, Gözlem Gazetecilik Basın ve Yayın A.Ş., İstanbul 2001, s. 389. Hagada'da, 'Bu, Atalarmızın Misır divarnnda yedikleri elem ekmĕgidir" denilmektedir. Haggada, Pesah Sederi'nde sirasiyla yapilacakları ortaya koyan bir metindir. Seder masasında Haggada okumak, bir mitzva (kutsal görev)'dır.

6 'Ve Misır'dan çıkardıklar hamurdan mayasız pideler pişirdiler; çünkü mayası gelmemişti; çünkü Mısır'dan kovuldular, bekleyemediler ve kendileri için de ą̧ k yapmamışlardı". Çı1kış 12:39.

7 Pentateuch'te, yani Tora'nın ilk 5 kitabinda.

8 Hasat Bayramı ya da ilk mevvenin hasat günü. Bkz. Jewish Values, s. 288.

9 Çardak Bayramı.

10 "Ve siz mayası ekmek bayramm tutacaksımz......Birinci ayda aym on dördü günü akesamindan aym yirmi birinci günü akşamına kadar mayasız ekmek yiyeceksiniz”. Çıkış 12: 17-18. Nazlı Doenyas, Pesah 
Ha Matzot ${ }^{11}$. Pesah ad1, Misırliların başına gelen 10 musibet sirasinda, İsrailoğulları'nı bunlardan bağışı tutan mucizevi kutsal korumayı anlatmaktadır. Tora'da, "Tanr İsrailoğullarmm evlerinin üzerinden geçti” sözleriyle, (Pesah=Passover=Üzerinden atlayarak geçme) anlatılmaktadır. Bu olay, daha sonraki yıllarda Süleyman Tapınağı'nda bir kuzunun kurban sunulmasıla anılmıştır. Hag Ha Matzot adı ise, bayram boyunca sadece mayasız ekmek olan hamursuzun yenebileceğini anımsatmaktadır ${ }^{12}$.

Pesah Bayramı hazırlığı şöyledir: Önce, evler iyice temizlenerek, hamets'ten ${ }^{13}$ arındırılır. Normal maya ile mayalanmış olmasa dahi, un ve su karıştıktan ve 18 dakika durduktan sonra doğrudan hamets kabul edilir. Tüm ekmek, bisküvi, hamur işi, viski ${ }^{14}$ ve bira ${ }^{15}$ gibi içkiler hamets'dir. Sadece taze sebze, meyve, yumurta ve Pesah için özel olarak hazırlanmış anlamına gelen Koşer le Pesah ${ }^{16}$ ürünler yenilmektedir. Özellikle Pesah'tan önceki gece, ev iyice temizlendikten sonra tek bir hamets'in gözden kaçırılmaması için kontrol edilir. Bu kontrolde, hamets düşmüş olabilecek koltuk köşeleri, çekmeceler hatta ceket cepleri bile aranır. Pesah boyunca hamets yemek, hatta hamets sahibi olmak yasaktır. Hamets yasağ1 nedeniyle, Pesah öncesi tüm hametsler ya yenir, ya başkalarına verilir, ya yok edilir, ya da yakilır veya satılır.

Bayramının anlam ve önemini şu sözcüklerle betimlemektedir: "Pesah Bayraminda, Yabudilerin Misır'da 210 yul süren esaretlerinden Tanr'nın Mucizeleri ile Tanr'nın Halkı olmak üzere kurtarlmalar kutlanır. Mısır'dan Çııss, Yabudilerin hayatının vazgeçilmez bir kısmım olușturur. O kadar ki, On Emir'in ilkinde, sabab-akșam söylenen Şema duasinda, Kidus duasinda, her günkü ve bayramlara özul dualarda

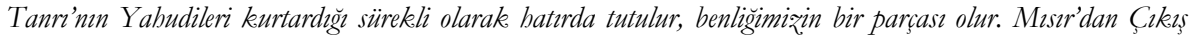
sadece 3332 ynl önce gerçekleşen bir olay değil, bugünümüzde, biz̨i esir eden ve ilerlememizi engelleyen, kendimiżin

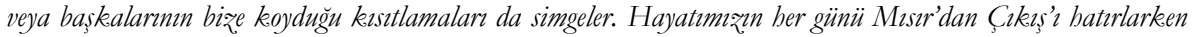
kendi Misır'larmı̨ın da farkına varmaya ve bunlar kırarak özgür olmaya çalışırz". Nazlı Doenyas, "Pesah'a Hazırlanıyoruz", Şalom, 31 Mart 2020 Salı.

11 İbranice olan Hag Ha Matzot'un Türkçe karşılığı, Hamursuz Bayramıdır.

12 Alalu (ve diğerleri), Yabudilikte Kavram ve Değerler, Gözlem Gazetecilik Basın ve Yayın A.Ș., İstanbul 2001, s. 12-13.

13 Mayalanmış undan hazırlanan her türlü yiyecek.

14 Viski, arpa, buğday, çavdar veya mısırdan damıtılarak yapılan ve meşe fiçılarda dinlendirilerek olgunlaştırılan bir tür alkollü içkidir. İsmi İrlanda ve İskoçya lehçelerinde yaşam suyu anlamına gelen uisge beatha'dan gelmektedir. Viski yapmak için mısır, arpa, çavdar ve hatta karabuğday gibi çeşitli tahıllar kullanılır.

15 Bira tahıldan üretilir: Yaygın olarak malt arpa kullanılır ama buğday, mısır ve pirinç de kullanılan ürünler arasındadır. Yapım aşamasında şıra (malt-su karışımı) içerisindeki nişastanın fermantasyonu sonucu etil alkol ve karbondioksit açığa çıkar ve bira köpügüne sahip bira meydana gelir.

16 Koşer, Helâl anlamına gelir. 


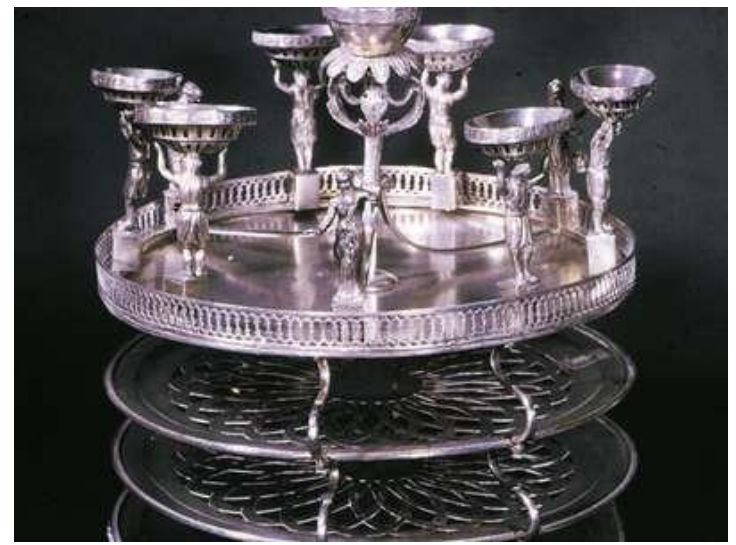

Fotoğraf 1. Seder'de kullanılan tepsi. Kaynak: plate-Vienna-Jewish-Museum-New-York-City1807. https://www.britannica.com/topic/Passover

Pesah Bayramı'nın ilk iki gecesi seder yap1lır ${ }^{17}$. Seder'de, aile bir araya toplanır. Pesah hikâyesi okunur, dört kadeh şarap içilir, Tanrı'yı kutsayan bir beraha okunur ve sembolik yiyecekler yenir. Bu yiyeceklerden biri Hamursuz'dur. Diğerleri; Maror ${ }^{18}$ : Geçmişte İsrailoğullarının yaşadı̆̆1 ac1 olayları temsil eder. $\operatorname{Karpas}^{19}$ : Seder'in başında, İsrailoğullarının ağlayışlarını hatırlamak için gözyaşlarını simgeleyen sirkeye batırılarak yenir. Haroset: Siyah kuru üzüm veya elma, hurma, tarçın karışımı ile hazırlanan bir tatlı bir karışımdır. Görüntü olarak çamura benzer ve kölelik yıllarında çamur içinde çalışmak zorunda kalan Yahudileri ve yaptıkları inşaat harcını hatırlatır. Zeroa ${ }^{20}$ : Kudüs'teki eski tapınak Beit-Hamikdaş'da sunulan kurbanlarin anısina hazırlanır ${ }^{21}$.

Orta Doğu'da ve Avrupa'da, bazı bölgelerde halâ hüküm süren eski bir gelenek mevcuttur: "Hayatını̨n tüm günlerinde Mısır topraklarından çıktrğını günü hatırlayın"22 pasajına sık1 sıkıya bağlı olan ve hatırlama fiilini görsele dönüştürmeyi tercih eden Yahudi topluluklarına ait sinagogların iç duvarında, tüm yıl boyunca tek bir hamursuz as1li tutulur ${ }^{23}$.

17 Seder, İsrail'de bir gece, İsrail dışında iki gece yapilir.

18 Ac1 otlar.

19 Kereviz Yaprağı.

20 Yanmıs kuzu kolu.

21 Alalu 2001, s. 19.

22 Tesniye 16:3.

23 Joseph, Jacobs- Eisenstein, Judah David, "Mazzah (plural Mazzot)", Jewish Encyclopedia, https://jewishencyclopedia.com/articles/14594-unleavened-

bread $\#$ sts $=\mathrm{MA} \% \mathrm{E} 1 \% \mathrm{BA} \% 92 \% \mathrm{E} 1 \% \mathrm{BA} \% 92 \mathrm{AH} \% 20$ (plural,$\% 20 \mathrm{Ma} \% \mathrm{E} 1 \% \mathrm{BA} \% 93 \% \mathrm{E} 1 \% \mathrm{BA} \% 9$ $\underline{3 o t}$. 


\section{Hamursuz (Matza) Yapimı}

İlk așama, Matza Șemura ${ }^{24}$ ana ham maddesi olan buğdayın, Pesah kurallarına göre toplanmasıdır. Halakha'ya ${ }^{25}$ göre, buğday, arpa, yulaf gibi hububat su ile temas eder etmez, 18 dakika içerisinde bir fermantasyon oluşmaya başlar. $\mathrm{Bu}$ yüzden, un ve sudan oluşan hamurun Matza olarak nitelendirilebilmesi için, 18 dakikadan önce pişirilmesi gerekir. Tora, hamursuz niteliği taşımayan yiyeceğin ${ }^{26}$ Hamursuz Bayramı boyunca tüketilmesini veya bulundurulmasını yasaklamaktadır. Üstelik Seder akşamında, en azından bir zeytin ağırlığı kadar hamursuzun tüketilmesini emretmektedir ${ }^{27}$. Hamursuz unu genellikle buğdaydan üretilmektedir. Fakat Tora'da adları zikredilen beş hububatı ${ }^{28}$ her hangi birinden de yapılabilir ${ }^{29}$.

Hamursuzun firınlanma işlemi, işlenecek hububat tanelerinin sudan korunması ile başlar. Her ne kadar, Halakha'ya göre, malzemenin sudan korunma hadisesi tanelerin un şeklinde ögütülmesiyle başlamaktaysa da; birçok koyu dindar Yahudi, hububat tanelerinin hasat aşamasından itibaren nemden korunmasını dikkatle gözetir. Bu şekilde hazırlanmış olan Hamursuz, Matz̧a Şemura (korunmuş hamursuz) olarak adlandırllır. Hamursuz, ilk yıllarda el kuvvetiyle öğütülürken; sonraki yıllarda makineler kullanılmaya başlanmıştır. Mayalanmamış hamurun oluşturulmasında kullanılan su bir gece dinlendirilmelidir. İlk yıllarda bu su gün batımında bir kuyudan veya nehirden sağlanmıştır. Ertesi sabaha kadar dinlendirilen su ${ }^{30}$;

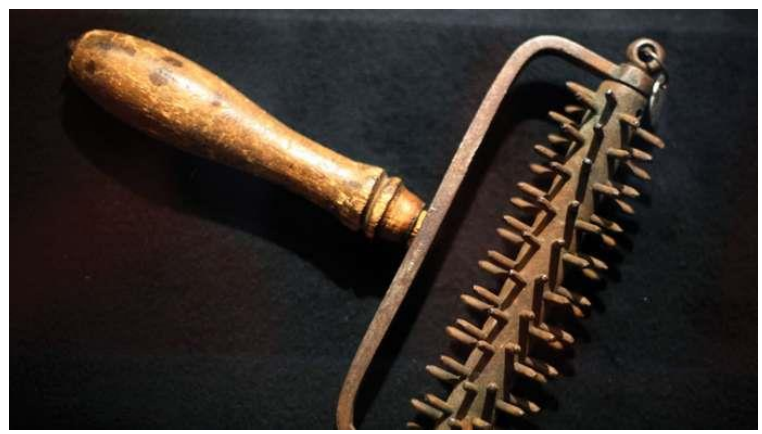

Fotoğraf 2. Meydana getirilen hamur yayıldıktan sonra, silindirle düzeltilmekte ve kabarmasının önlenmesi için ayrıca iğneli bir silindirden geçirilmektedir. Fotoğrafta iğneli silindir örneği mevcuttur. Kaynak: Tool-matzo-bread-wood-iron-New-York.

https://www.britannica.com/topic/Passover

24 İbranice olan bu sözcük korunmuş anlamına gelir. לשמור yani, korumak fiilinden türemiştir.

25 Halakha İbranice bir sözcüktür. Gitmek anlamına gelen, İbranice ללכת fiilinden türemiştir. Yahudilikte, sözlü ve yazılı aktarılan emir ve nehiyleri (yasakları) kapsayan genel bir dinî hukuk kavramıdır. Halakha, 613 emirden oluşmaktadır. Bunun 365’i yasakları içerir. Kaynak ise, Tora'dır.

26 Hamets niteliğine sahip yiyecek.

27 Çıkış 12: 15-20, 13:7. Pesahim 28b. 120a.

28 Buğday, arpa, spelt(bir çeşit buğday), yulaf ve çavdar.

29 Besalel 2001, 389. "MISHNA: Pesab'n ilk gecesi kişinin Matza yeme yükü̈mlülï̈̆̈̈nü yerine getirdiği tahıl türleri şunlarder : Buğday, arpa, heceli (kusmin), çavdar ve yulaf ....”. Talmud, Pesahim, 35a.

30 Talmud, Pesahim, 94b. 
korunmuş un ile karıştırılmakta; oluşan hamur yayıldıktan sonra, silindirle düzlenmekte ve kabarmasının önlenmesi için iğneli bir silindirden geçirilmektedir. En son da, 18 dakika içerisinde yüksek bir hararette firınlanmaktadır. Misır'dan Çıkış’n anısına Pesah Bayramı boyunca yenen Hamursuz’un pişirileceği tüm pişirme cihazları ve firın, hamurunun mayalanmaması için önceden hazırlanmaktadır ${ }^{31}$. Matza şemura, Seder gecesi yenen hamursuzdur. Siradan hamursuz ise, marketten ya da pazardan satın alınan un ile hazırlanmaktadır. Yapımında, firıncılar sadece yoğurma ve pişirme işlemi sırasında dikkatlidir. İlk gece, hamursuz yemek zorunlu olduğundan, eğer yeterli korunmuş hamursuz üretimi söz konusu değilse, sıradan hamursuz da servis edilmektedir. Yine de market ya da pazardan satın alınan unun, sadece buğday, arpa, spelt ${ }^{32}$, yulaf veya çavdardan üretilmesi zorunludur ${ }^{33}$.

Hamursuz yapımında, zaman çok önemlidir. Çünkü fermantasyondan özellikle kaçınılmaktadır. Bu bağlamda zaman kaybının fermantasyona yol açma riski nedeniyle, pasta, puding, kek ya da pandispanyanın yapımında siradan unun kullanılması yasaklanmıştır. Öte yandan, unun pişirildikten sonra fermantasyona uğraması mümkün değildir. Bu yüzden, hamursuzdan elde edilen unla pasta, puding, kek ya da pandispanya yapımına izin verilmiştir. Ayrıca, sıradan unun saf meyve suları, yumurta veya bal ile yoğrulması izni mevcuttur. Çünkü adlarını zikrettiğimiz katkı maddeleri, fermantasyona yol açmamaktadır. Bu şekilde elde edilen hamursuza verilen ad ise, "Zengin Matza" dir. Zengin Matza, birinci seder gecesi hariç, Hamursuz Bayramı süresince yenebilmektedir ${ }^{34}$.

\section{Hamursuz Pişirme Makinelerinin Kısa Tarihçesi}

Hamursuz, 19. yüzyılın ikinci yarısına değin yuvarlak formda ve yaklaşık on iki inç ${ }^{35}$ çapında elde imal edilmiştir. Hamursuz pişirme makinelerinin bulunduğu tarih, 1857 yllıdır. İlk hamursuz pişirme makinesi Avusturya'da icat edilmiş36 ve makinede hamursuz imalatı, yarım yüzyıl boyunca sürecek hararetli tartışmalara yol açmıştır. Dr. Solomon B. Freehof, tartışmalara ilişkin şu saptamayı yapmaktadır: "responsa literatürü taribindeki en sert tartısmalardan biri..." 37. Baz1 hahamlar, makine yapımı hamursuzun köşelerinin kırpılarak yuvarlak hale getirilmesi işleminden dolayı sürenin uzadığını; sürenin uzamasının ise, fermantasyona yol açtığını iddia ederek hamursuz makinelerine karşı çıkmışlardır. Hamursuz makinelerine karşı

31 Besalel 2001, 389.

32 Spelt, binlerce yıl önce Avrupa ve Orta Doğu'daki eski medeniyetler tarafindan yetiştirilen buğday türlerinden biridir.

33 Joseph-Eisenstein, "Mazzah (plural Mazzot)".

34 Talmud, Pesah 36a.

351 inç $=2.54 \mathrm{~cm}$.

36 Joseph ve Eisenstein'a göre, Hamursuz Makinesi'nin bulunduğu tarih 1875, bulunduğu yer ise İngiltere'dir. Bir süre sonra, Amerika'da da tanıtımı yapılacaktır. Bkz. Joseph-Eisenstein, "Mazzah (plural Mazzot)".

37 Philip Goodman, "The Matzah-Baking Machine - A 19. Century Controversy", https://www.myjewishlearning.com/article/the-matzah-baking-machine/. 
çıkanlardan biri, Brodyli Solomon Kluger'dir. Kluger'in en çarpıcı argümanlarından biri, yoksulların çalışma alanlarından birinin kaybolduğuna ilişkindir. Ona göre yoksullar, makinelerin varlığından dolayı, hamursuz fırınlarında çalışarak Pesah gereksinimleri için para kazanma fırsatını kaybetmiştir. Çünkü makine kullanımı daha az kol işçisi gerektirmektedir. $O$ ve yandaşları ayrıca Matza Şemura'nın, makinede imalatında sorunlar oluşabileceğini; makinenin tekerleklerinde kalan ve temizlenmesi zor olan hamur parçalarının mayalanacağından şüphelenildiğini iddia etmişlerdir. Makine kullanımını onaylayan hahamların başında yer alan Lembergli Joseph Saul Nathanson, muhalefetin iddialarını çürütmek için, elle yapılan

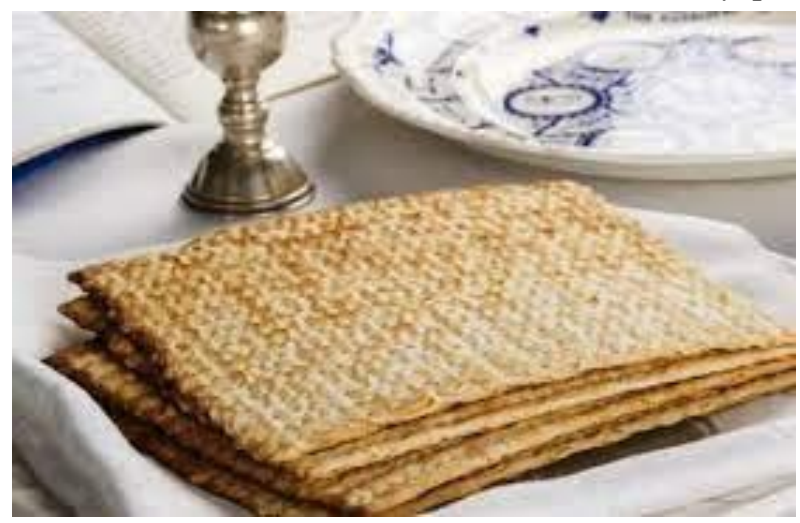

Fotoğraf 3. Kare biçimde üretilen hamursuz.

hamursuz imalatında çalışan fırıncıların işlerinin elinden alınmasıyla ilgili iddiaya karşılık matbaayı ve matbaanın uygarlığa olan katkılarını örnek vermiştir. S1k sık ve özenle temizlenen makinelerde, hamurun kalmasından endişe duyulmaması gerektiğini; makinenin hamursuz yapım sürecini hızlandırdığını ve gece gündüz hamursuz firınında çalışan kadın ve erkek işçilerin eskiye oranla daha verimli olduğunu ilave etmiştir. Nathanson'ın görüşleri, pek çok Yahudi tarafindan kabul görmüştür ${ }^{38}$. Yoğun protesto ve şiddetli itirazlar devam ettiği için, hamursuzun şekli bir kareye dönüştürülmüş ve böylece makinede üretime devam edilmiştir. Buna rağmen, makine yapımı hamursuzu yuvarlak formda kullanmayı tercih edenler mevcuttur. Öte yandan, el yapımı hamursuz kullanan dindarların sayısı da az değildir ${ }^{39}$.

\section{İzmir'de Hamursuz Üretimi}

Hamursuz üretiminin geçirdiği tarihi süreci yukarıda kısaca izah ettik. İzmir'de de, Yahudi cemaati tarafindan bir hamursuz makinesi alınıncaya değin, hamursuz üretimi elde yapılmıştır. Hamursuz, başlangıçta yuvarlak formludur. Makineleşmeyle birlikte kare forma dönüşmüştür.

38 Goodman, "The Matzah-Baking Machine - A 19. Century Controversy".

39 Joseph-Eisenstein, "Mazzah (plural Mazzot)". 
İzmir'de ilk hamursuz fabrikası, Nesim Levi Bayrakl140 tarafından kurulmuştur. Kuruluş tarihine ve yerine ilişkin elimizde bir bilgi mevcut değildir. Ancak Birinci Dünya Savaşı sırasında, sözünü ettiğimiz makinelerin, Levi tarafından Tire'ye taşındığı bilinmektedir. Bunun sebebi ise, savaşın imparatorlukta yol açtığ1 buğday kıtlı̆̆ından dolayı hamursuz üretiminde çeşitli zorlukların yaşanmasıdır. Cumhuriyetin ilk yıllarında, Tire Yahudi Cemaati'nden Hayim Saban ile Nesim Levi arasında yapılan bir anlaşma sonucu, Hamursuz makinelerinin mülkiyeti, Hayim Saban üzerine geçmiştir. Bu tarihten itibaren Tire, hamursuz imalatının merkezi olarak yükselmiş; makinelerde üretilen hamursuz, İzmir'e ve civar kentlere dağıtılmıştır. 1930'lu yıllarda ise, Tire merkezli hamursuz üretiminin sorumluluğu, Yosef Duenyas'a devredilmiştir ${ }^{41}$.

\section{İzmir Hamursuz Fabrikası}

24 Nisan 1945 tarihinde, İzmir Yahudi Cemaati Başkanı Sabetay Saltiel tarafından New York Yahudi Cemaati'ne bir mektup yazılmıştır. Saltiel mektubuna, İzmir'deki hamursuz fabrikasının eski bir sisteme sahip köhne bir makine olduğunu anlatarak başlamaktadır. Demek ki, 1930 ile 1945 yılları arasındaki zaman diliminde, ya Tire'deki eski Hamursuz Makinesi İzmir'e geri taşınmış; ya da İzmir Yahudi Cemaati için bir Hamursuz Makinesi satın alınmıştır. Her ne şekilde temin edilmiş olursa olsun; makinenin eski olduğu aşikârdır. Makinenin eskiliŭgi, her Hamursuz Bayramı sırasında kaliteli hamursuz üretimini zorlaştırmaktadır. Bu sebepten dolayı İzmir cemaati, 1945 yılında, hamursuz üretimi için ihtiyaç duyulan makineleri içeren modern bir fabrika kumaya karar vermiştir. Fabrika kurulduktan sonra, Hamursuz Bayramı başlamadan birkaç hafta önce hamursuz üretilmeye başlanacak; yılın geri kalan zamanlarında ise bisküvi ve makarna üretimi yapılacaktır. Mektupta, New York Yahudi Cemaati'nden talep edilen, Hamursuz makineleri üreten uzman firmaların adlarına ilişkin liste, bu firmalara ait referanslar, makinelerin komple imalat kapasiteleri ve fiyatlarıdır. Son olarak, İzmir'de 3 faz 50 çevrim 220 volt elektrik akımının kullanıldığı belirtilmiştir ${ }^{42}$ (Bkz. Belge 1). Hamursuz Fabrikası'nın inşa edileceği yer, Güzelyurt Mahallesi 920 sokak numara 42'de, 922 sokak numara 18/18-A'daki arazidir. Bu arazi, 170 metrekare olup, Hahamhane bahçesinde yer almaktadır. Eskiden, 119

40 Nesim Levi Bayraklı hakkında ayrıntılı bilgi için bkz. Siren Bora, Karataş Hastanesi ve Cevresinde Yahudi İzleri, İzmir Büyükşehir Belediyesi Ahmet Piriştina Kent Arşivi ve Müzesi Yay., İzmir 2015, s. 181-187.

41 Siren Bora, Başlangı̧tan Günümüze Tire'de Yabudi İzleri, Tire Belediyesi Kültür Yay., Ankara 2017 s. 114. Avram Galante, Histoire des Juifs de Turquie, İstanbul tome III, t.y., s. 33. Avram Galante, Histoire des Juifs d'Anatolie, İstanbul 1939, 2 me volume, s. 343.

42 Central Archives for the History of the Jewish People, Turkey/Izmir, 585. 24 Nisan 1945 tarihinde, İzmir Yahudi Cemaati Başkanı Sabetay Saltiel tarafından New York Yahudi Cemaati'ne yazılan mektup. 
metre karelik kısmında Hahambaşılı̆̆ın eski kârgir kütüphanesi mevcuttur ${ }^{43}(\mathrm{Bkz}$. Belge 2).

Önce, satın alınacak olan Hamursuz makinesi seçilmiştir. Makine, İtalyan üretimi OFFERTA 221'dir"4 (Bkz. Belge 3 ve 4a/4b). 26 Haziran 1946 tarihinde ise, İzmir Belediyesi ESHOT Müdürlüğüne baş vurularak, 25 kilovat enerji talebinde bulunulmuştur. Eylül ayında, Saman İskelesi Buldanlı Zade Han No 7'de iş yeri sahibi ve Yahudi cemaatine mensup Mühendis A. Ziffer ile temasa geçilmiştir. Ziffer, bir keşif yapmış ve hazırladığ1 "Hamursuz. Fabrikası AvanProjesini45”, 10 Eylül 1946 tarihinde İzmir Yahudi Cemaati yönetimine sunmuştur ${ }^{46}$. Projeye eklenen şemada, elektrik fırını, yoğurma makinesi, şekil verme silindirleri, yürütücü şasisi ve depoların yerleri ayrıntılı olarak gösterilmektedir ${ }^{47}$ (Bkz. Belge 5). Ziffer, 15 Ekim 1946 tarihinde, İzmir Yahudi Cemaati Konseyi'ne hitaben yazdığ1 yazıda, "Inșa etmek istediğiniz Hamursuz Fabrikasın, avan projeye uygun șekilde ve hamur makinesinin mermer kısm size ait olmak üzere 14.000 liraya tesisatın üzerime almayı kabul ederim" taahhütünde bulunmuştur ${ }^{48}$ (Bkz. Belge 7). İzmir'de 825'inci Ata Sokağ1'nda 5 numaralı evde ikamet eden Bohor Halegu ile Albert Ziffer arasinda 11 maddelik bir anlaşma yapılmıştır. İnşaatın mükellefi İzmir Hahambaşıllı̆1 olduğu için, Hahambaşılıktan Bohor Halegu'nun, Hamursuz Fabrikası'nın yapımına ilişkin her türlü sorumluluğu üstlenmek üzere görevlendirildiği anlaşılmaktadır ${ }^{49}$ (Bkz. Belge 8a/b). İnşa edilecek firın, saatte 50 kilo hamursuz randımanı verebilecek kapasitede olacaktır. Ayrıca 3. maddeden anlaşıldı̆̆ına göre, eğer Hahambaşılık ileride arzu ederse, firın ufak bir tadilatla bisküvi imal edebilecek hale dönüştürülebilecektir. A. Ziffer, 24 Ekim’de Hamursuz Fabrikası inşaatının teknik şartnamesini teslim etmiştir. Şartname, elektrik fırını, elektrik firınının nakil şeridi, hamura şekil verme silindirleri, hamur makinesi, elektrik tesisatı ve kayıt adlı 6 ana başlık altında açıklamalardan oluşmaktadır. ${ }^{50}$ (Bkz. Belge 9a/b/c). 9 Ekim 1946 tarihinde, İzmir Hahambaşıllı̆ı ve Sabetay Saltiel başkanlığında, Moris Celardine, Bohor Alazraki, Nesim Danon, Jak Albağl1, Elyezer Levi, Yosef Gomel, Alber Arditi ve Bohor Gargir'den oluşan İzmir Yahudi Cemaati Yönetim Kurulu ${ }^{51}$, Elektromekanik Mühendisi D. Barki ile bir toplantı yapmış ve onu, 28 Ekim'de kontrol mühendisi olarak tayin etmiştir. Barki'nin üstleneceği görev karşıllğında

43 CAHJP, TR/İ‡, 585. İzmir Özel Saymanlık Varidat Müdürlüğü’ne verilen inşaat beyannamesi.

$44 \mathrm{CAHJP}, \mathrm{TR} / \bar{I}_{z}, 585$. OFFERTA 221 'in fotoğrafi ve makinenin özelliklerine ilişkin İtalyanca tanitım belgesi.

45 Avan Proje, bir ön hazırlık projesidir. Proje örneklerinde, detayları görmek mümkün değildir. Sadece kabataslak bilgi verilir. Bu yüzden, yapı elemanları bu projede yer almaz.

46 CAHJP, TR/İ, 585. Mühendis A. Ziffer tarafindan hazırlanan Hamursuz Fabrikas1 Avan-Projesi.

47 CAHJP, TR/ $\dot{I}_{2}$, 585. Mühendis A. Ziffer tarafindan çizilen Hamursuz Fabrikası şeması.

$48 \mathrm{CAHJP}, \mathrm{TR} / \dot{I}_{\mathscr{V}}$, 585. 15.10.1946 tarihinde, A. Ziffer tarafindan İzmir Cemaat Konseyine yazılan resmi yazi.

49 CAHJP, TR/ $\dot{I}_{\text {F, }}$ 585. Bohor Halegu ile Albert Ziffer arasında yapılan anlaşmanın iki sayfalık metni.

50 CAHJP, TR/ $\dot{I}_{z}, 585$. A. Ziffer tarafindan hazırlanan teknik şartname.

51 CAHJP, TR/İ, 585. 9 Ekim 1949 tarihli Ladino belge. 
alacağ1 ücret, toplam $700 \operatorname{lirad}^{5}{ }^{52}$. Barki tarafından, inşa edilecek Hamursuz Fırını'na ilişkin bir şema çizlmiştir (Bkz. Belge 6). Bu şema, Ziffer'in şemasından farklıdır. Barki şemasında, inşaatın mimari ayrıntılarına eğilmiş ve koridorlar, wc, depolar ve merdivenlere ilişkin bilgi vermiştir ${ }^{53}$.

İnşaatın ruhsat tezkeresi, 28 Aralık 1946 tarihinde alınmıştır. 30 Aralık’ta da inşaata başlanmıştır. Yap1, 170 metrekarelik arsa üzerine beton ve kârgir olarak inşa edilmektedir ${ }^{54}$. Bohor Halegu tarafindan, Hamursuz Fabrikasının İnşaat Hesabı ve Hamursuz Fabrikasının Makine Kısmı Hesabı başlikları altında ödemeleri içeren ayrı bir defter açılmıştır. 22 Kasım 1946 ile 12 Mart 1947 tarihleri aasında, hem inşaata hem de makine bölümüne yapılan harcamalar ayrı sütunlara, tek tek kaydedilmiştir (Bkz. Belge 10a/b/c). İnşaatın bitiş tarihi 5 Mart 1947'dir. O halde, defterde kayıtlı harcamaların 12 Mart'ta sonlanması doğaldır. Hesap defterindeki kayıtlar, inşaat arazisindeki eski yapının yıkım masrafi ile başlamaktadır. Yıkım için ödenen ücret 225 liradır. Sonra, kurşun boru, demir, tuğla, kum, çakıl, kereste, çimento, kilit, teneke, cam, kurşun, kap1, menteşe, mermer tozu ve muhtelif harcamalar yine başlıkları altında listelenmiş ve her birine ödenen ücretler tek tek yazılmıştır. Yekŭn, 1.081 lira 043 kuruştur. Ayrıca defterde, inşaatın ince işçiliğinde görev alanların adları mevcuttur: Barki, Yosef Sigura, Ribi David, Bohor Sadi ve Bohor Halengu. Yapının inşa masrafı toplam 2004 liradır. Makine k1smı için ise harcanan para ise, toplam 11.399.73 liradır ${ }^{55}$. Hamursuz Fabrikası inşaatı 5 Mart'ta tamamlandıktan sonra, 19 Mart Çarşamba günü, saat 17.40'ta Hamursuz (Elektrik) Fabrikasının elektirik sayac1 262.40 kilovatsaatte durdurulmuştur. O dakikadan itibaren, sarf edilecek kilovatsaat, aboneliğe sahip olan Bohor Halugu'ya aittir. Zabıt varakasının altında, Cemaat Başkanı Sabetay Saltiel, Cemaat Azası Elyezer Levi, Yüksek Mühendis D. Barki ve Makinist Hasan Yurdayol'un imzaları mevcuttur. ${ }^{56}$.

\section{Sonuç}

İzmir Hamursuz Fabrikasının inşaat öyküsü, iki açıdan önem arz etmektedir: Bunlardan ilki, Albert (Avraham) Ziffer'in, 1895 y1lında İstanbul'da, dünyadaki ilk Yahudi spor kulübünü kuran 12 kişi arasında yer almasıdır. Diğeri ise, yapılan fabrikanın, Türkiye'nin ilk Hamursuz Fabrikası vasfını taşımasıdır.

Albert Ziffer, 8 Ocak 1895 tarihinde, on iki Yahudi gençle birlikte, "Israelitische Turnverein Konstantinopel'i (İstanbul Jimnastik Kulübü) kurmuştur. Kendisi de atletlerden biridir. Bu kulüp, orta sinıfa mensup Yahudi gençlerin egzersiz yaptı̆̆ı, vücutlarını çalıştırdığı, sosyalleştiği ve eğlendiği bir merkezdir.

52 CAHJP, TR $/ \dot{I}_{2}, 585.28$ Ekim 1946 tarihli D. Barki'nin görevi kabul ettiğine ilişkin belge.

53 CAHJP, TR/ $\dot{I}_{2}$, 585. Kontrol Mühendisi olarak tayin edilen D. Barki tarafindan çizilen şemadır.

54 CAHJP, TR/İz 585. İzmir Özel Saymanlık Varidat Müdürlüğü'ne verilen İnşaat Beyannamesi.

55 CAHJP, TR/İz, 585. Hamursuz Fabrikasının İnşaat ve Makine Kısmı Hesapları.

56 CAHJP, TR/İ̌, 585. Elektirkle çalışan Hamursuz Fabrikası'nın elektriğine ait 19 Mart 1947 tarihli Zabıt Varakası. Ayrıca belgeye elle bir not düşülmüştür: "25 Mart 1947 taribinde saat 13.40'ta, odun ocaklar ile sayaçin indeksi 28.645 kilovatsaattedir". 
Kulüp, hayırsever topluluk ünvanıyla, “Goldschmidt Okulu”na bağlı gösterilmiştir. Aynı zamanda, Avusturya koruması altındadır. Kulübe üye gençlerin nereyse tamamı, akıcı Almanca konuşmaktadır. Ailesi, 19.

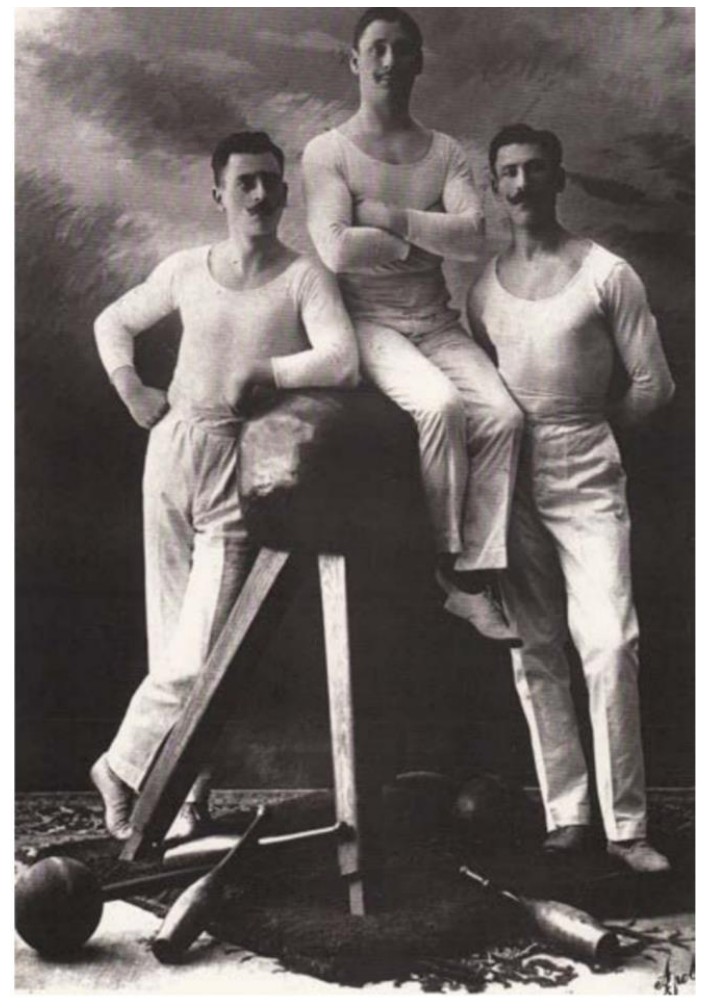

Fotoğraf 4. Soldan sağa: J. Kornfeld, L. Shoenmass ve Albert Ziffer, 1907 yllında İstanbul Jimnastik Kulübünde. Kaynak: Murat Cihan Yıldız, Strengthening Male Bodies and Building Robust Communities: Physical Culture in the Late Ottoman Empire, (Doctor of Philosophy in History- Unpublished $\mathrm{PhD}$ Thesis), University of California Los Angeles 2015, s. 82.

yüzyllın sonlarında, Romanya Galatz'dan İstanbul'a göç eden Albert (Avraham) Ziffer, Aşkenaz Yahudisidir. Uzun yıllar, jimnastik kulübünün başkanı ve antrenörü olarak görev yapmışıtır. Yidiş̧ ${ }^{77}$, Almanca, Fransızca, Rumence, Osmanlıca ve Türkçe bilmektedir ${ }^{58}$. 1903 ile 1919 ylları arasında, Avusturya Macaristan temsilcisinin tercümanı olarak görev yapan ve Düyun-u Umumiye'de çalışan Ziffer'in hangi tarihte İzmir'e geldiği bilinmemektedir. Muhtemelen,

57 Yidiş, Aşkenaz Yahudileri tarafından kullanılan, İbranice ve Almanca'nın karışımından oluşmuş Yüksek-Almanca dil grubuna dahil bir dildir.

58 Murat Cihan Yildı, Strengthening Male Bodies and Building Robust Communities: Physical Culture in the Late Ottoman Empire, (Doctor of Philosophy in History- Unpublished PhD Thesis), University of California Los Angeles 2015, s. 77-82. 
Cumhuriyet Dönemi'nde İzmir'e yerleşen Ziffer'in elektrik mühendisi olduğu aşikârdır. Albert Ziffer tarafindan kaleme alınan ve 24 Ekim'de teslim edilen Hamursuz Fabrikası inşaatının teknik şartnamesinin üçüncü sayfasında yer alan açıklamada, İzmir Hamursuz Fabrikası'nın, "Türkiye'de ilk olarak ve hiçbir numune

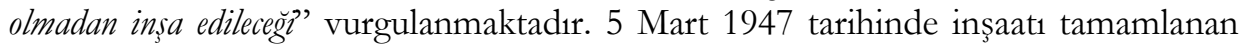
ve 5 Mayıs 1947 tarihinde İzmir Belediyesi Makine ve Elektrik Mühendisliği'nden "Kuvvei Mubarrike Rubsatnamesi"ni alan ${ }^{59}$ İzmir Hamursuz Fabrikası, anlaşıldığına göre, Türkiye'de bir ilke imza atmıştır. İnşa edildiği esnada, ülkede benzer bir örneği mevcut değildir. Bu yüzden, fabrikaya ait Ziffer’in çizimleri ve dosyada yer alan tüm teknik ayrıntılar son derece önemlidir.

\section{Kaynaklar}

\section{Central Archives for the History of the Jewish People}

CAHJP, TR/İ, 585. 24 Nisan 1945 tarihinde, İzmir Yahudi Cemaati Başkanı Sabetay Saltiel tarafindan New York Yahudi Cemaati'ne yazılan mektup.

CAHJP, TR/İ, 585. İzmir Özel Saymanlık Varidat Müdürlüğü’ne verilen inşaat beyannamesi.

CAHJP, TR/ $\dot{I}_{2}, 585$. OFFERTA 221'in fotoğrafı ve makinenin özelliklerine ilişkin İtalyanca tanitım belgesi.

CAHJP, TR/İ, 585. Mühendis A. Ziffer tarafindan hazırlanan Hamursuz Fabrikası AvanProjesi.

CAHJP, TR/İ, 585. Mühendis A. Ziffer tarafindan çizilen Hamursuz Fabrikası şeması.

CAHJP, TR/İ , 585. 15.10.1946 tarihinde, A. Ziffer tarafindan İzmir Cemaat Konseyine yazilan resmi yazi.

CAHJP, TR/İ, 585. Bohor Halegu ile Albert Ziffer arasında yapılan anlaşmanın iki sayfalık metni.

CAHJP, TR/ $\dot{I}_{2}, 585.28$ Ekim 1946 tarihli D. Barki’nin görevi kabul ettiğine ilişkin belge.

CAHJP, TR/Ǐz, 585. 9 Ekim 1949 tarihli Ladino belge.

CAHJP, TR/İ, 585. Kontrol Mühendisi olarak tayin edilen D. Barki tarafindan çizilen Hamursuz Fabrikası şeması.

CAHJP, TR/İ 585 . Hamursuz Fabrikasının İnşaat ve Makine Kısmı Hesapları.

CAHJP, TR/İz, 585. Elektirkle çalışan Hamursuz Fabrikası'nın elektriğgine ait 19 Mart 1947 tarihli Zabit Varakası.

CAHJP, TR/İ, 585. 5 Mayıs 1947 tarihinde, İzmir Belediyesi Makine ve Elektrik Mühendisliği’nden alınan "Kuvvei Muharrike Rubsatnamesi".

\section{Kitaplar ve Makaleler}

Alalu, Suzan-Arditi, Klara-Asayas, Beki- Basmac1, Teri- Ender, Fani- Haleva, Beki- Maya, Dalya- Pardo, Ninet- Yanarocak, Sara, (Altıntaş, Yusuf, II Baskıya Hazırlayan), Yabudilikte Kavram ve Değerler, Gözlem Gazetecilik Basın ve Yayın A.Ş., İstanbul 2001.

59 CAHJP, TR/ $\dot{I}_{2}$ 585. 5 Mayis 1947 tarihinde, İzmir Belediyesi Makine ve Elektrik Mühendisliği’nden alınan “Kuvvei Mubarrike Rubsatnamesi”. 
Besalel, Yusuf, Yabudilik Ansiklopedisi, Cilt 2, Gözlem Gazetecilik Basın ve Yayın A.Ş., İstanbul 2001.

Bora, Siren, Karataș Hastanesi ve Cevresinde Yahudi İzleri, İzmir Büyükşehir Belediyesi Ahmet Piriştina Kent Arşivi ve Müzesi Yay., İzmir 2015.

Bora, Siren, Başlangıstan Günümüze Tire'de Yabudi İzleri, Tire Belediyesi Kültür Yay., Ankara 2017.

Doenyas, Nazlı, "Pesah’a Hazırlanıyoruz”, Şalom, 31 Mart 2020 Salı.

Galante, Avram, Histoire des Juifs de Turquie, İstanbul t.y., tome III.

Galante, Avram, Histoire des Juifs d'Anatolie, İstanbul 1939, 2 me volume.

Jewish Values, Israel Pocket Library - Keter Publishing House Jerusalem Ltd., Jerusalem 1974.

Kitabı Mukaddes Eski ve Yeni Abit, Kitabı Mukaddes Şirketi İstanbul 1988.

Y1ldı, Murat Cihan, Strengthening Male Bodies and Building Robust Communities: Physical Culture in the Late Ottoman Empire, (Doctor of Philosophy in History- Unpublished PhD Thesis), University of California Los Angeles 2015.

\section{Elektronik kaynaklar}

Goodman, Philip, “The Matzah-Baking Machine - A 19. Century Controversy", https://www.myjewishlearning.com/article/the-matzah-baking-machine/ . (erişim tarihi:0 3.11.2021).

Hirsch, Emil. "Passover", Jewish Encyclopedia, https://jewishencyclopedia.com/articles/3343-bitter-herbs. (erişim tarihi: 03.11.2021).

Joseph, Jacobs- Eisenstein, Judah David, "Mazzah (plural Mazzot)”, Jewish Encyclopedia, https://jewishencyclopedia.com/articles/14594-unleavened-

bread\#sts $=$ MA $\%$ E $1 \%$ BA $\% 92 \%$ E $1 \%$ BA $\% 92 \mathrm{AH} \% 20$ (plural, $\% 20 \mathrm{Ma} \% \mathrm{E} 1 \% \mathrm{BA} \% 93$ \%E1\%BA\%93ot). (erişim tarihi: 03.11.2021).

https://www.sefaria.org/Pesachim.35a?lang=bi. (erişim tarihi: 04.11.2021).

https://www.sefaria.org/Pesachim.94b?lang=bi. (erişim tarihi: 04.11.2021).

https://www.britannica.com/topic/Passover . (erişim tarihi: 03.11.2021). 
Türkiye'de Bir İlk: İzmir Matza (Hamursuz) Fabrikası Hakekinda Belgeler

\section{BELGELER}

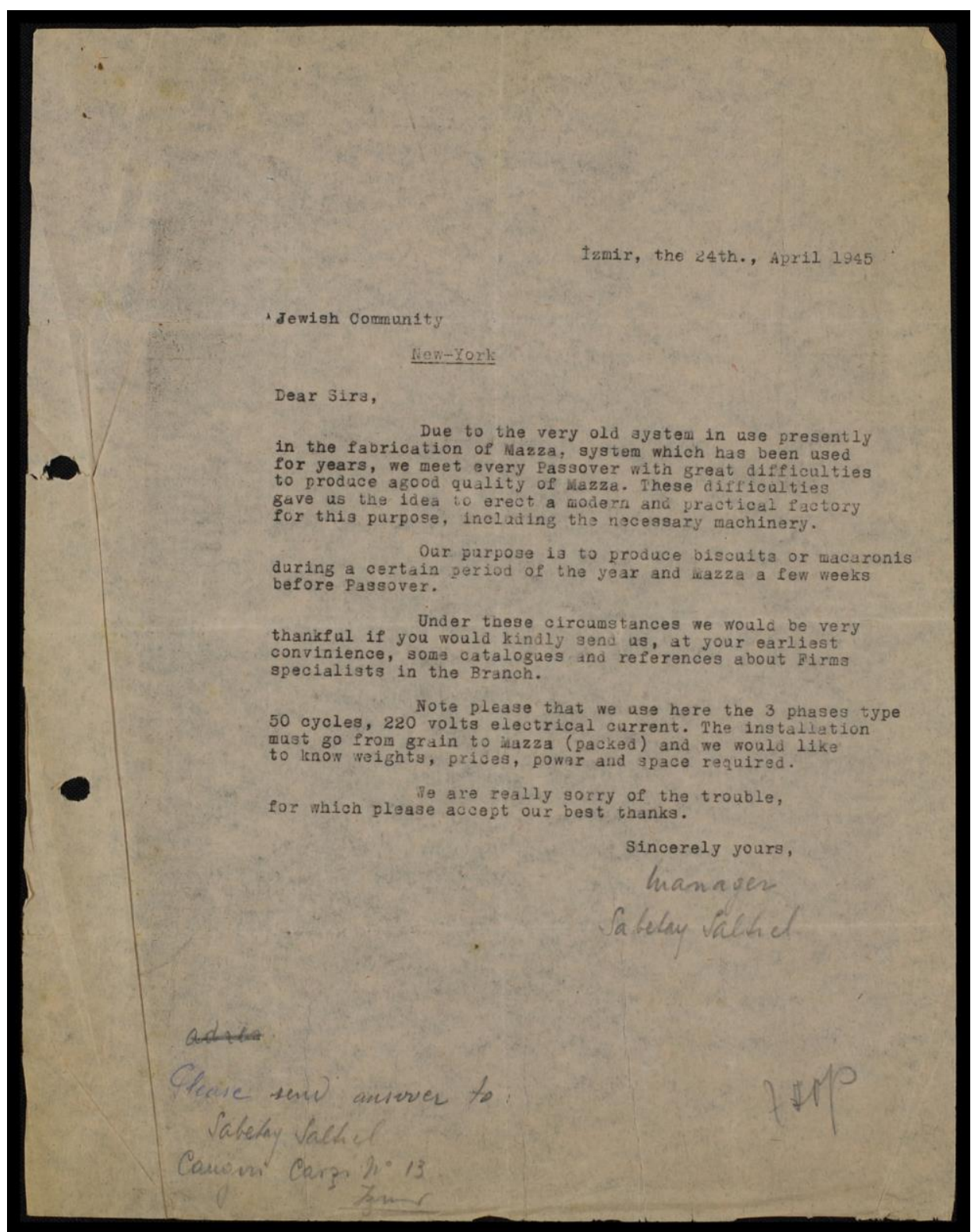

Belge 1. 24 Nisan 1945 taribinde, İzmir Yabudi Cemaati Başkam Sabetay Saltiel tarafindan New York Yabudi Cemaati'ne yazllan mektup. Kaynak: CAHJP, TR/İ, 585. 
TZUIR OZEL SAYMANLIK SAYIN

VAR TDAT MUDURLUGUNE

Ozü : Inşaat Beyannamesidir.

MUKELIEF : tzmir Hahambaşılığı. - tzmir, Güneş, 920 nci sokak, No.42.

UZERINE BINA YAPILAN ARSA : trmir, Güneş Mahallesi, 922 nci sokair, No.18.

(arsanin 119 metre murabbal kısminda evvelce hahambaşılığın kârgir küüuphanesi vardı. Yeni inşaat eski binay tadilen ve temamen içerisine almış bulunmaktadır).

BINANIN ISGGI ETIIGI ARSANIN SATH M MESAHASI : 170 metre murabbaz.

INSAATIN NEV'1 : Beton ve kârgir.

ISTIMAL TARZI : Elektrik firinl.

INSAATIN BASSLADIGI TARIH : 30/12/1946.

INSSAAT RUHSAT TEZKERESININ : Tarihi : 28/12/1946

No. : Cilt 29, s1ra 13.

INSAATIN BITTIGI TARIH : 5/3/1947.

IZMIR HAHAMBAŞILIGI

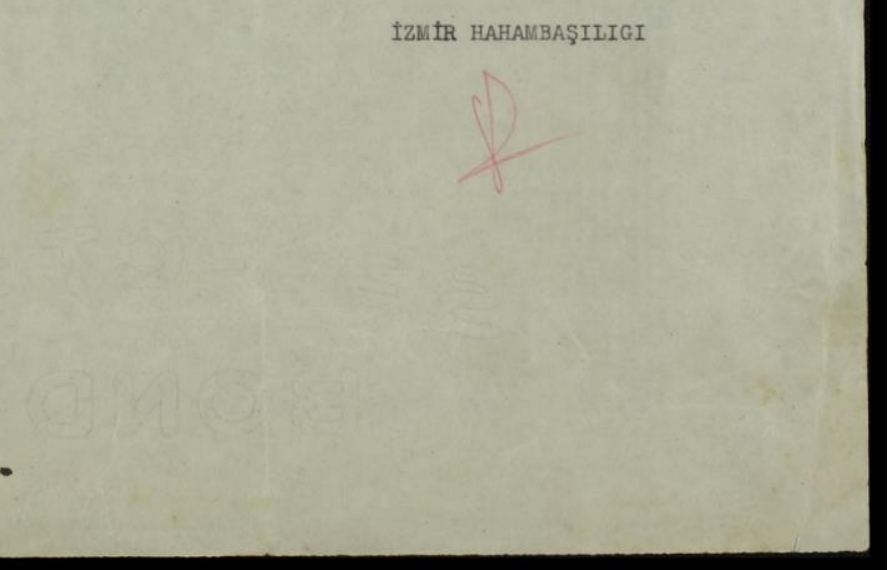

Belge 2. İzmir Özel Saymanlık Varidat Müdürlügü’ne verilen İnsaat Beyannamesi. Kaynak: CAHJP, TR/İ, 585. 
Türkiye'de Bir İlk: İzmir Matza (Hamursuz) Fabrikası Hakekinda Belgeler

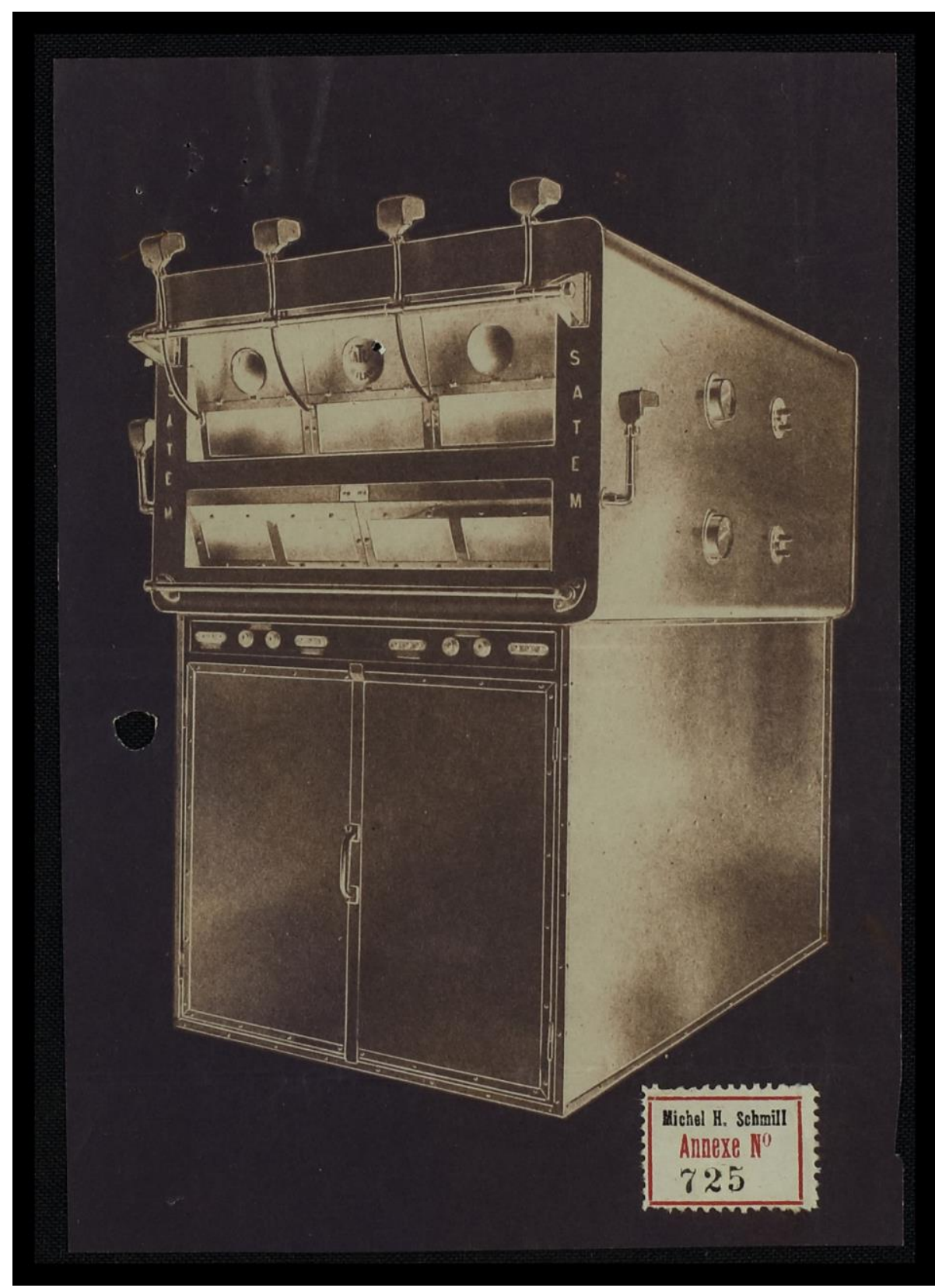

Belge 3. OFFERTA 221 'in fotoğrafi. Kaynak: CAHJP, TR/İz, 585. özellikelerine iliskin İtalyanca tantum belgesi. 


\section{OBFARTA Nr. 221}

Nr. I Forno elettrice a radiazion1-superficle mq;?

\begin{tabular}{|c|c|c|c|}
\hline 1 mensi & $\begin{array}{l}\text { profondità } \\
\text { larghezza }\end{array}$ & $\mathrm{m} / \mathrm{m}$ & $\begin{array}{l}3800 \\
2300\end{array}$ \\
\hline & altezza & $n$ & 1800 \\
\hline D1mension1 interne: & mrofonalta & $n$ & 3500 \\
\hline & larghezza & " & 2000 \\
\hline & altezza & $n$ & 200 \\
\hline
\end{tabular}

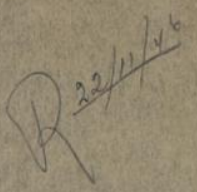

Dor-no eropriamente detto - composto al involucro esterno in alluminio con

- guarnizioni laternli-nr. 4 bocohe dinfornamento - no; 1 pirometro - no. 1

a. posamano - no 1 oblo per l'lliuminazione Interna della cameradi cottura- no;1 valvola di scarico del vapore -no l capa di raccolta del vapore uscente dalla camera di cottura durante l'esere1z10-no. lomera di lievitazione.-

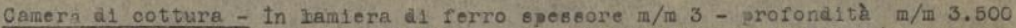
larghezza $\mathrm{m} / \mathrm{m} 2000$-altezza $\mathrm{m} / \mathrm{m} 200$ - con tunnel al prolunga di $150 \mathrm{~m} / \mathrm{N}$ alla bocoa d'infornamento.

Parte elletr10a: Bitunta esternamente alla oamera al cottura composta di no 2 placohe con resistenze elettriche platte di puro nichel cromo delle almension Q1 $3500 \times 2000$.

Camera d1 1801 amento - olroostante tutto 11 forno con applicazione di pannell1

in magnesio intonaoati con magnesile caustuca spessore $150 \mathrm{~m} / \mathrm{m}$ o altro materiale PREZZO: L1t. 675,000 Lst.520

Coneerna: 60 glorni dall'ordine B.1.

Paramento: $50 \%$ all'oralne- $50 \%$ alla conegna

Merce: resa franco nostro domalldo

Imbal10: eventuale al costo

Nr.I INPASTATRIOE: da KE. $80 .$.

PREzZO : L1t.187.500 Lst.14h

GARANZIE Per quento concerne le rebistenze elettriche le durata z assiourata per 18 meb1, con riferimento alle norme stablilte dalia C;E. 1 . - Tutte le parti mecoa-

niche vencono da nol garantite per la durata a1 12 mes 1 dal collaudo. per tutte

le altre concizions sono valide le nostre condizioni generall di valita.

HODOTTO: S1 garn tisce una cottura perfetta ea una resa sul cotto non inferiore ella perenetuale stabilita dalle Autorità Sanitarle. escludendo qualo1as 1 carto

Belge 4a. OFFERTA 221 'in öz̧elliklerine iliskein Italyanca tantom belgesinin ilk sayfası. Kaynak: CAHJP, $\mathrm{TR} / \dot{I}_{2}, 585$. 
Türkiye'de Bir İlk: İzmir Matza (Hamursuz) Fabrikası Hak.kinda Belgeler

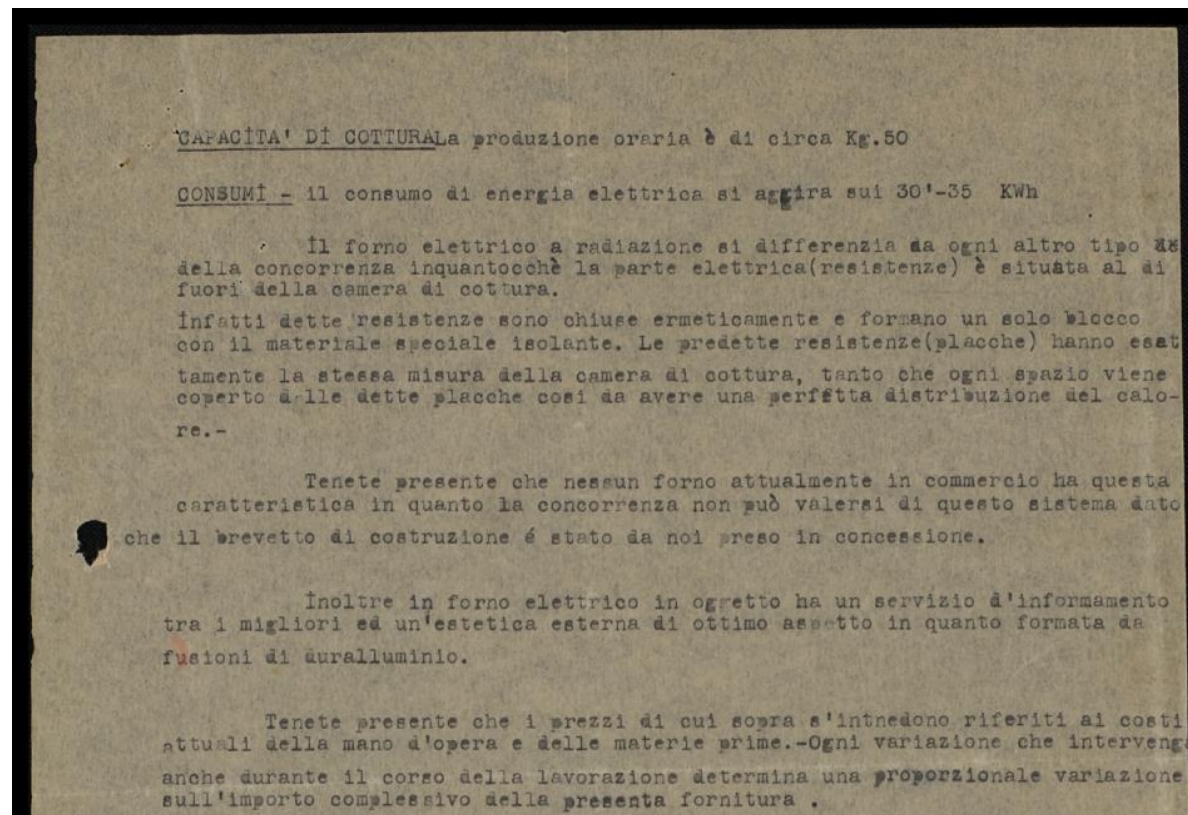
suli'importo complessivo della presenta fornitura.

Belge 4b. OFFERTA 221'in özelliklerine ilişkin Italyanca tantım belgesinin ikinci sayfası. Kaynak: CAHJP, $T R / \dot{I}_{z}, 585$. 
Siren Bora

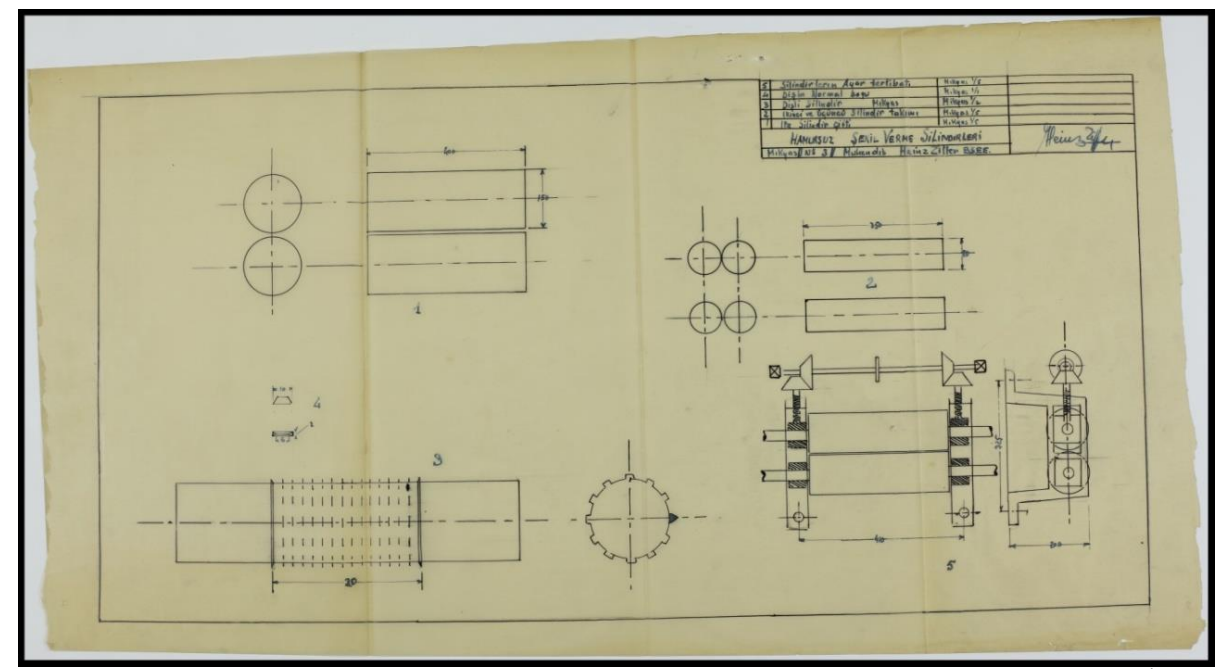

Belge 5. Bu șema, Hamursuz Firnnna ait olup, A. Ziffer tarafindan çizilmiştir. Kaynak: CAHJP, TR/Ǐ, 585.

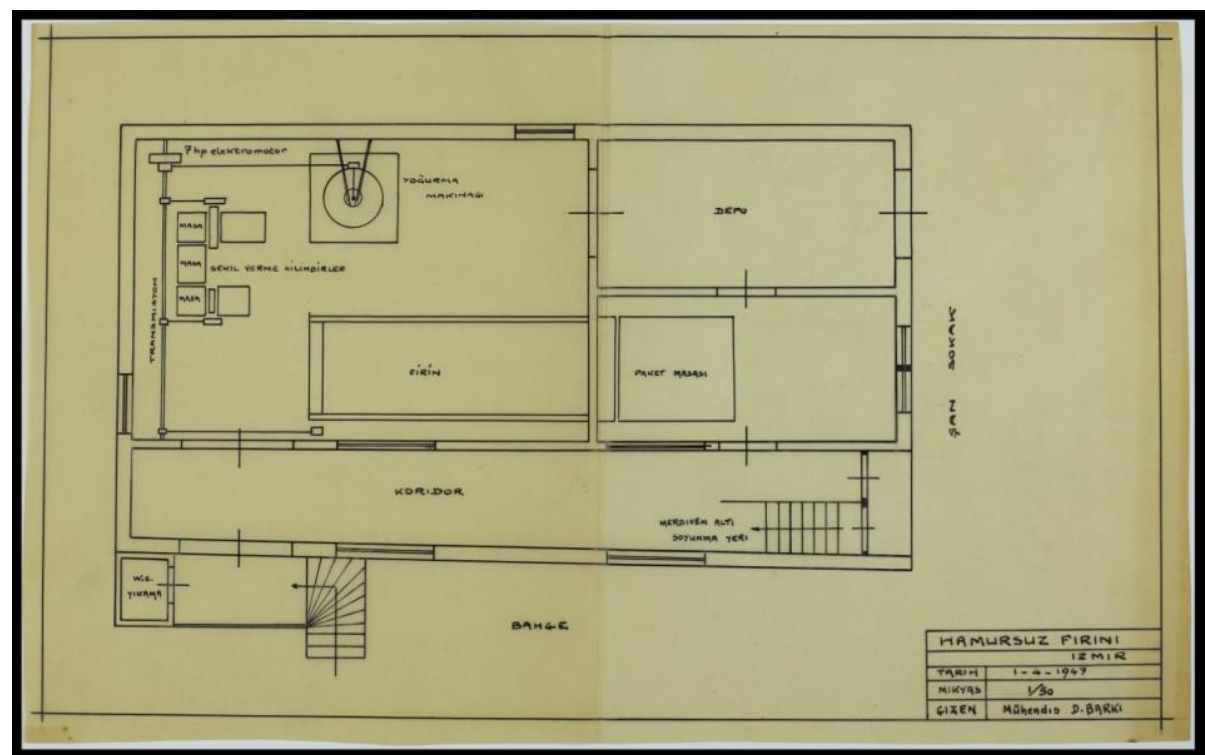

Belge 6. Bu şema, Kontrol Mühendisi olarak tayin edilen D. Barki tarafindan çizilen Hamursuz Fummmın semasidır. Kaynak: CAHJP, TR/İ, 585. 


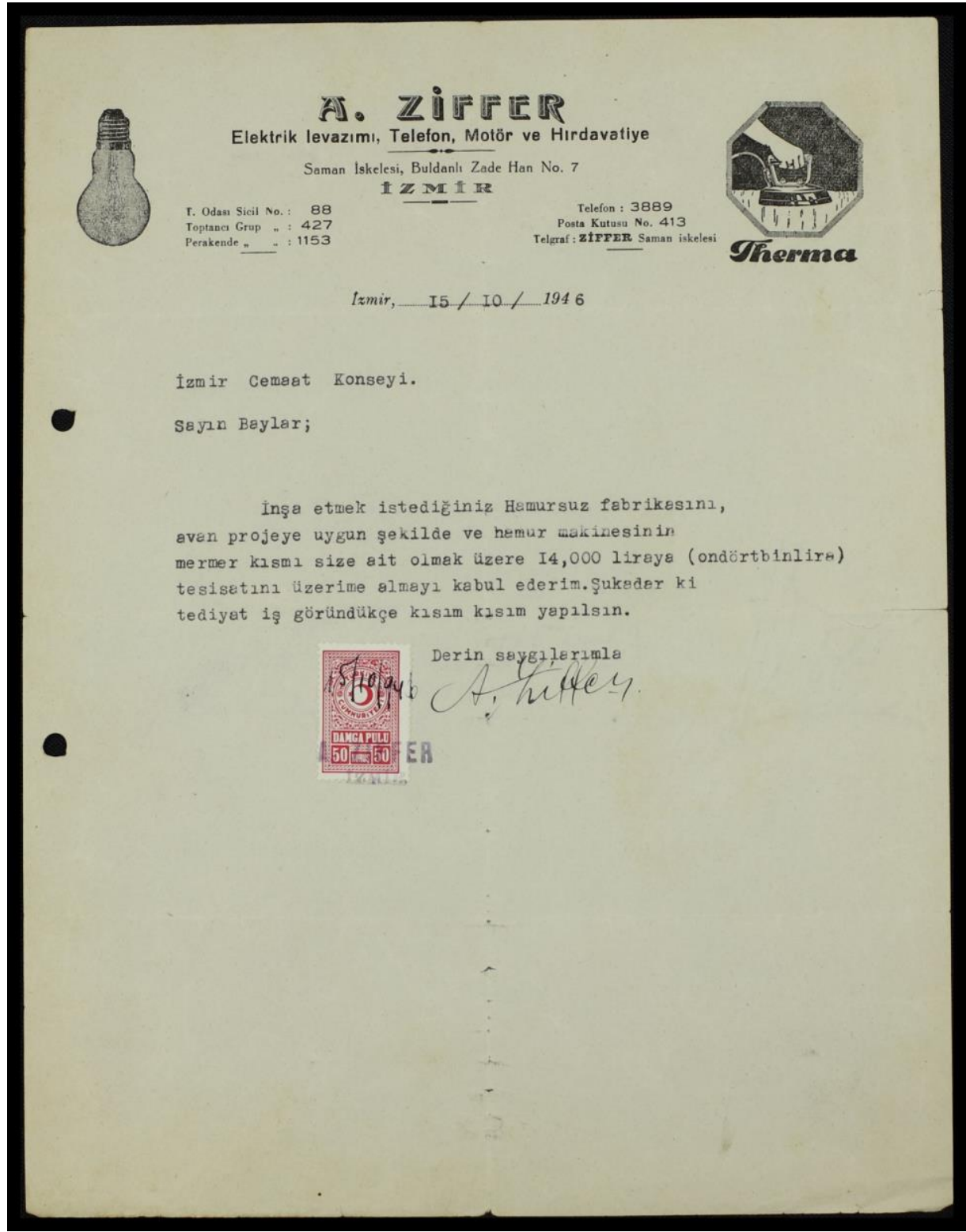

Belge 7. 15.10.1946 taribinde, Albert Ziffer tarafindan İmir Cemaat Konseyine yazllan resmi yaz.. Kaynak: CAHJP, TR/Ǐ, 585. 
Bir taraftan Izmir'de, 825 Inci Ata sokağında 5 No.lu evde oturan Bohor Halegua ve diger taraftan Izmir'de, 'Mimar Kemalettin Caddesinde, Buldanll Hanında, 7 No. da ticaret yapan Albert Zlffer arasında aşağıdaki şartlarrla bır anlaşma yapılmıştır :

Madde 1 - Albert Ziffer Izmir'de, 920 ncz sokakta, tzmir Hahambaşılığı arsasında aşağı da yazılı şartlarla işbu anlaşmada kısaca fırın tabir edilen tesisatin kurulmasını ve teslimini tahhhid eder.

Madde 2 - Firun, hamursuz imaline mahsus ve başlıca elektromotorler, silindirli şekil verme makinasiyle elektrik firını kısımlarından mirekkep bïtiln teferruatın 2 havi ve elektrik kuvvetiyle mijteharrik ve mikemmel surette işlex bir halde tesis ve teslim edileceirtir.

Madde 3 - Fırın 1cabında asgari tadilât ve masrafla biskivit imaline mahsus bir şekle 1fră̆ı mímkin evsafta olacaktır. Bu tadilât yaplldıŏ takdirde masraflarz Bohor Halegua'ya ait olacaktır.

Madde 4 - Firınin yeni olarak butiun malzemesi ve tesis masrafları minhasıran Albert Ziffer'e ait olacaktır. Ancak, yoğurma ameliyesine ait iki mermer taş Bohor Halegua tarafından temin edilecektir. Bununla beraber bu mermex taşlarının montajı da Albert Ziffer'e ait olacaktre.

Wadde 5 - Yoğurma taşlarının ve silındirli şekil verme makinssinin dobnmeler1, silindirierden gikan hamurun muayyen şekil dairesinde kesilmes1 ve noktalanması, hamursuzlarin firlnda ayarli ve mitemadi bir sistem dairesinde p1şmesi ameliyeleri elektrik kuvvetiyle ceryan edecekt1r.

Madde 6 - Firin saatta en az elli kilo randiman verecek evsafta olscakt2r.

Madde 7 - Bohor Halegua, firznan gerek malzemesini gerek tes1sini mihendis Barki marifetiyle tesis ameliyesinin başından sonuna kadar ve her daim kontrol etmek selâhiyetini halzdir. Albert zlffer bütin işler de bu kontrol muhendisiyle mutabik olarak hareket etmeyi taahhüd eder.

Madde 8 - F2rıaın evsafı hakkında tarafların imaasınız taşıyan şartname işbu anlaşmanın ayrzlmaz bir eizii sayılır. Şartnamede sarahat olmayan hususlar hakikında Albert Zlffer kontrol milhendisinin mutabakatının istihsal edeceictir.

Belge 8a. Bohor Halegu ile Albert Ziffer arasinda yapılan anlasmann birinci sayfası. Kaynak: CAHJP, TR/Iซ, 585. 


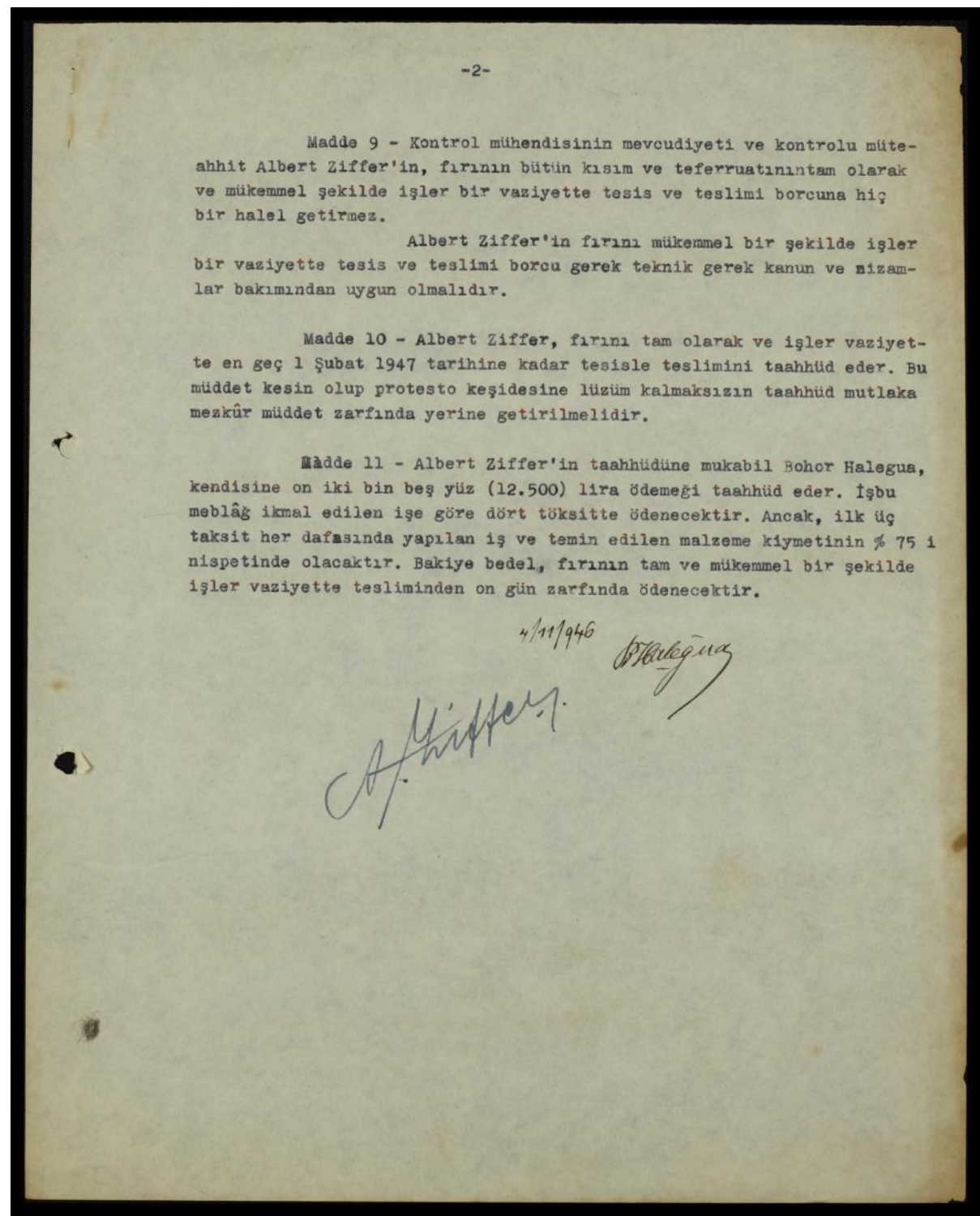

Belge 8b. Bohor Halegu ile Albert Ziffer arasında yapılan anlașmanın ikinci sayfası. Kaynak: CAHJP, TR/Iz; 585. 


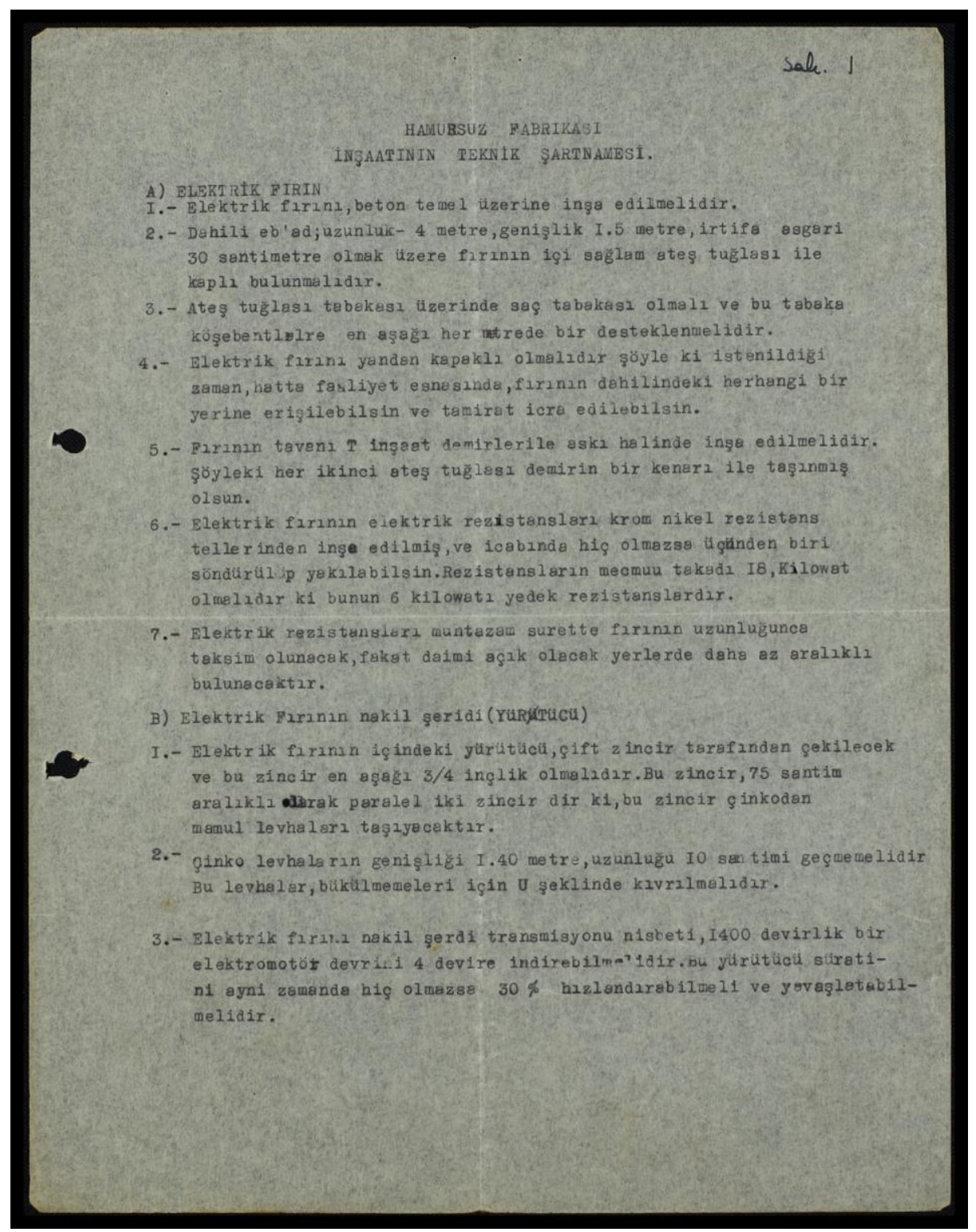

Belge 9a. Hamursuz Fabrikasi'nn Teknik Sartnamesi. Sayfa 1. Kaynak: CAHJP, TR/İz, 585. 
Türkiye'de Bir İlk: İzmir Matza (Hamursuz) Fabrikası Hakekinda Belgeler

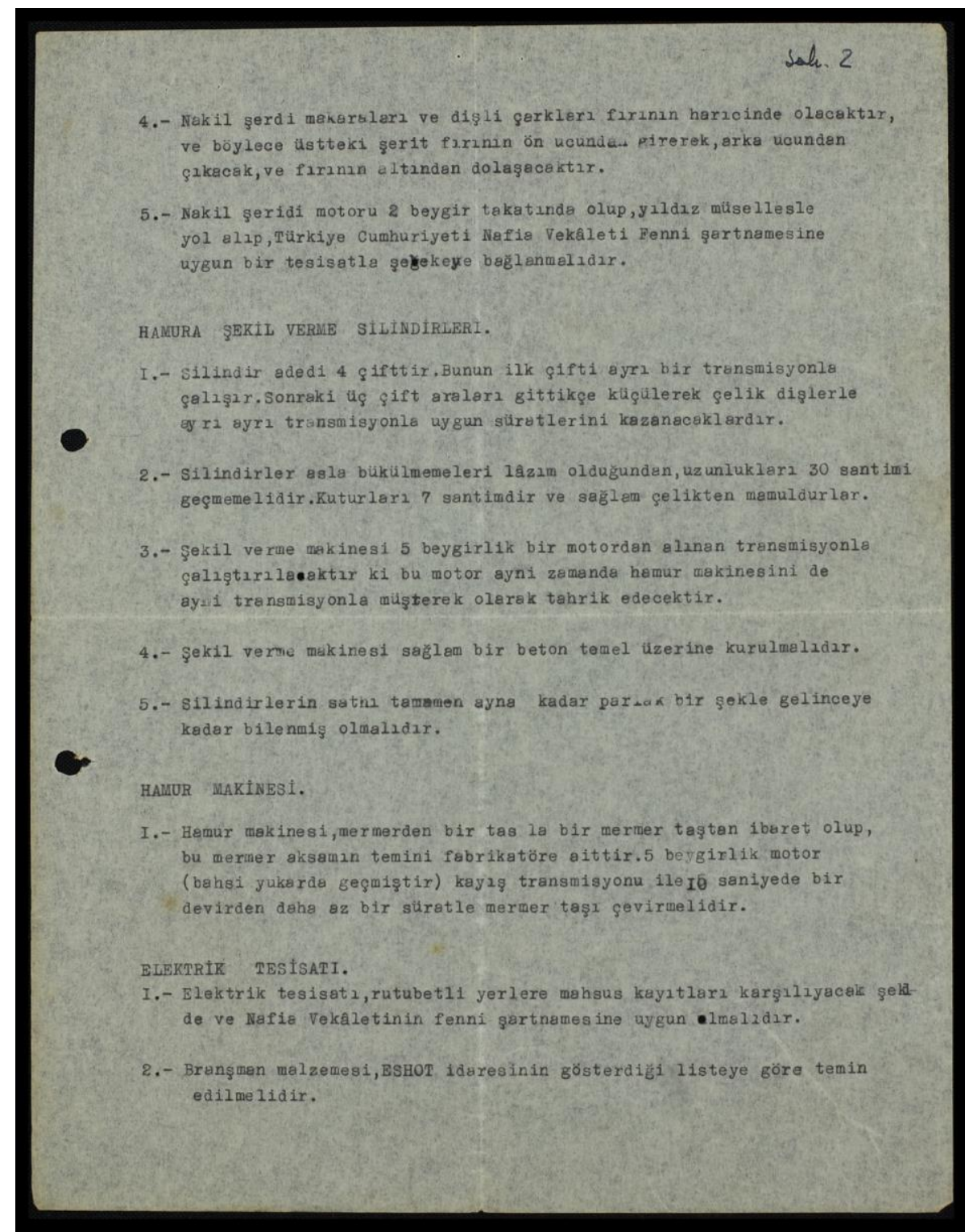

Belge 9b. Hamursuz Fabrikasi'nn Teknik Șartnamesi. Sayfa 2. Kaynak: CAHJP, TR/İ, 585. 


\section{KAYIT:}

Hemursuz fabrikası, Türkiyede $11 \mathrm{k}$ olarak ve hiç bir nümune olmadan inşa edileceğinden planlar ve hatta şartnamedeki kayıtlar teknik z orluklarla karşılaştı̆̈l takdirde, lüzuđlu de ह̌işıklikler, fenni kaldeler uyduklar takdirde, lora edilmesine müsaade edilir.

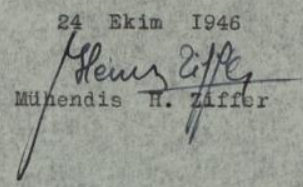

Belge 9c. Hamursuz Fabrikasi'nn Teknik Şartnamesi. Sayfa 3. Kaynak: CAHJP, TR/Iz, 585. 
Türkiye'de Bir Ilk: İmir Matza (Hamursuz) Fabrikası Hakeknda Belgeler
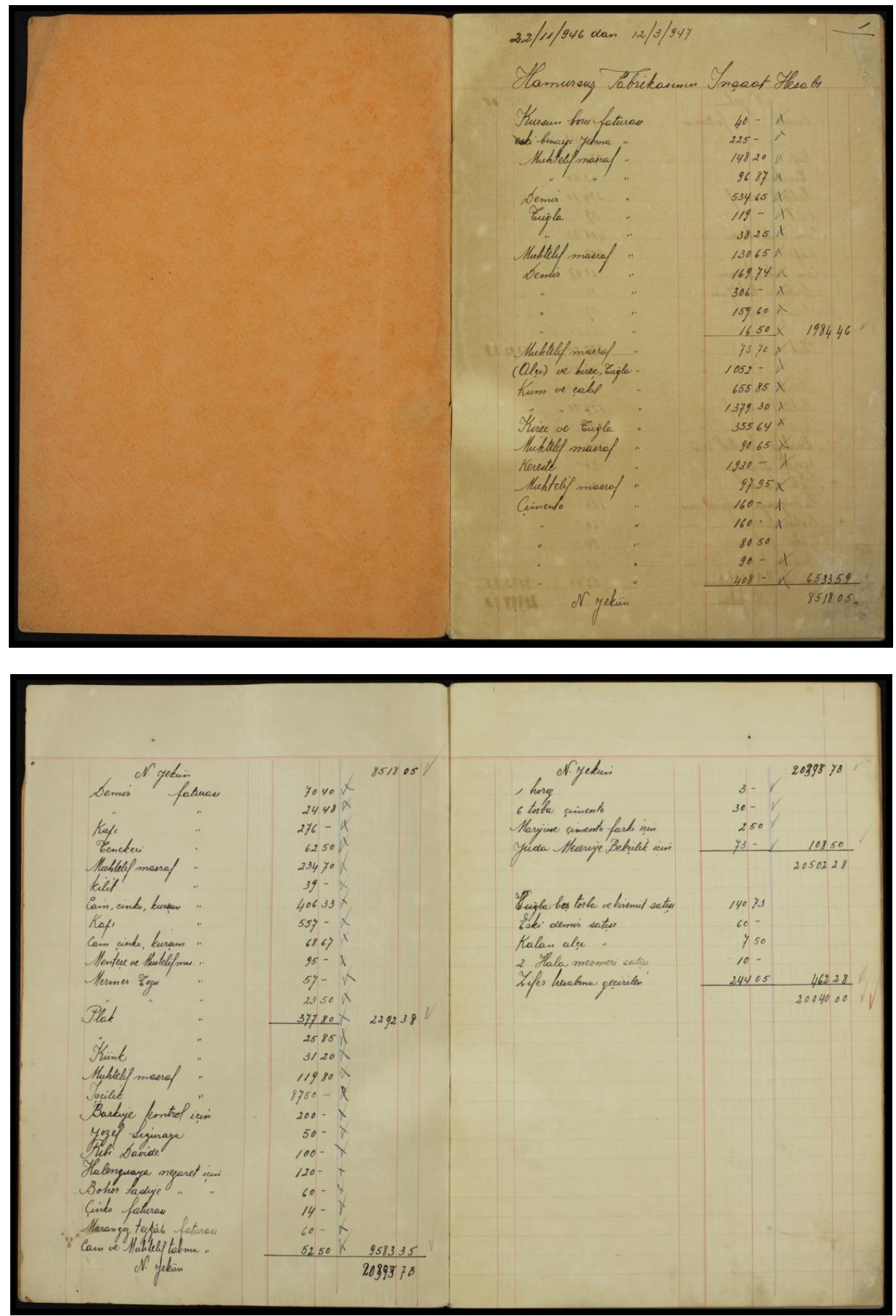

Belge 10a/b. Hamursuz Fabrikasmm Inşaat Hesabı. Kaynak: CAHJP, TR/İø, 585. 
Siren Bora

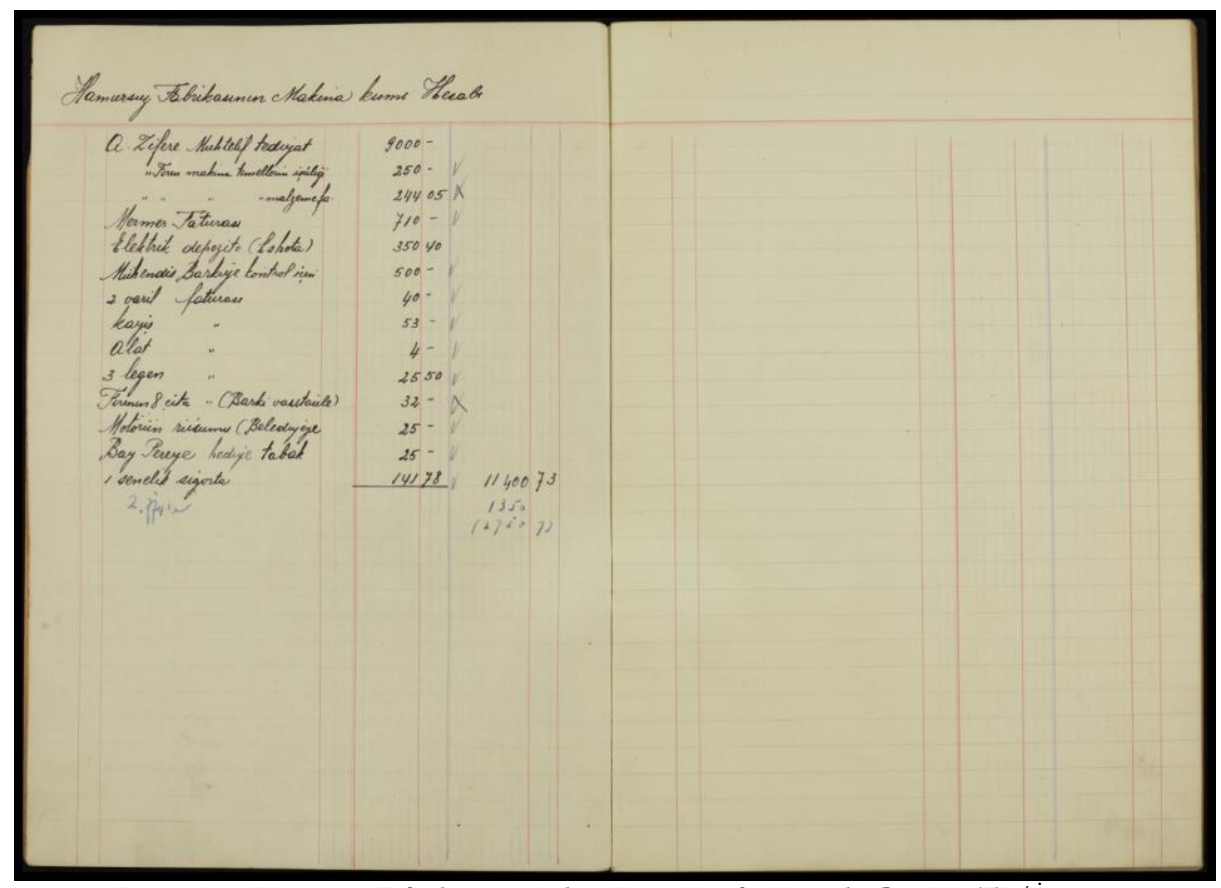

Belge 10c. Hamursuz Fabrikasmmn Makine Kısmı Hesabı. Kaynak: CAHJP, TR/İz, 585. 